\title{
(DE) SENTRALISME KEKUASAAN: \\ KEDUDUKAN PEMIMPIN TERHADAP KASUS RECALL DALAM KAJIAN \\ KONSEP AHLUL HALLI WAL 'AQDI
}

\author{
Lutfi Fahrul Rizal \\ Fakultas Syari'ah dan Hukum UIN Sunan Gunung Djati Bandung \\ Jl. A. H. Nasution Nomor 105 Bandung \\ Email: lutfifahrulrizal@gmail.com
}

\begin{abstract}
Abstrak
Seorang pemimpin merupakan perwujudan dari apa yang dipimpinnya. Maka ia pula yang menjadi ukuran keberhasilan atau tidaknya suatu keadaan yang dipimpinnya. Recall merupakan salah satu hak partai politik yang bisa dikatakan "istimewa" dewasa ini, maka dari itu boleh dikatakan bahwa 70\% kekuasaan negara dimiliki oleh partai politik. Dalam kasus recall terdapat banyak permasalahan dan kontroversi, terutama menyangkut alasan, mekanisme dan penyelesaian sengketa recall. Kontroversi penyelesaian sengketa recall melalui lembaga peradilan TUN mempermasalahkan kedudukan seorang pemimpin, yang dalam hal ini adalah presiden. Sebagian kalangan mengatakan perkara recall boleh diproses di peradilan TUN dan sebagian lagi mengatakan tidak boleh dengan alasan tindakan presiden tersebut hanya bersifat pasif atau hanya sebatas "pengamin" saja, maka tidak dikatakan sebagai tindakan tata usaha negara. Hal ini cukup menarik untuk dikaji dengan memfokuskan kepada sikap seorang presiden atau pemimpin terhadap kasus recall dalam konsep Ahlul halli wal 'aqdi.
\end{abstract}

Kata kunci:

Ahlul halli wal 'aqdi, Recall, dan Partai Politik

\section{A. Pendahuluan}

Kehidupan berbangsa dan bernegara merupakan suatu kepastian yang harus dialami dan digeluti oleh masing-masing individu manusia yang hidup di abad kontemporer ini. Predikat "bangsa" dan "negara" menjadi suatu keharusan yang dimiliki, karena dua hal tersebut merupakan identitas yang menjadi karakter dalam pergaulan internasional. 
Berbeda dengan zaman pra-sejarah atau zaman sebelum peradaban yang dimana ketika itu manusia hidup berkelompok dan berpindahpindah (nomaden), namun kini tidak bisa dilakukan secara bebas begitu saja, ada syarat dan ketentuan yang harus dipenuhi, semua terjadi karena "identitas" tersebut.

Kesadaran manusia untuk hidup berkelompok ada ketika Adam sebagai manusia pertama yang diciptakan oleh Allah SWT diciptakan, ketika itu Adam merasa tidak bisa untuk hidup seorang diri, karena ia memiliki hak kodrati kebutuhan dan ketergantungan terhadap yang lainnya, hal ini yang dinamakan fitrah. Salah satu fitrah dalam kasus ini adalah kebutuhan terhadap lawan jenis, oleh karena itu Allah pun menciptakan Hawa dari tulang rusuknya sebagai teman yang akan menemani keberadaan Adam.

Socrates pernah mengatakan, bahwa manusia merupakan makhluk "Zoon Politicoon", yaitu makhluk yang senantiasa berusaha untuk bertahan dari segala aspek kehidupan, karena hal tersebut ia memerlukan bantuan dan kelebihan orang lain untuk menutupi kekurangan yang dimilikinya.

Bangsa dan negara Indonesia, merupakan suatu identitas. Suatu bangsa dan negara memerlukan suatu syarat khusus yang lebih penting, yaitu keberadaan seorang pemimpin yang merupakan jelmaan atau perwujudan dari sekian banyak penghuni bangsa yang terhimpun di dalamnya. Salah satunya yang lebih kita kenal dengan sebutan Presiden Republik Inonesia. Didalam Pasal 4 Ayat (1) UUD Republik Indonesia, disebutkan bahwa:

"Presiden Republik Indonesia memegang kekuasaan pemerintahan menurut Undang-Undang Dasar."

Keberadaan presiden sebagai lembaga eksekutif berdasarkan sistem pemerintahan yang dianut oleh negara Indonesia tidak mungkin bisa berjalan dengan efektif dan efisien, maka dibutuhkan lembaga legislatif dan yudikatif sebagai bagian dari kesatuan pemerintahan yang saling melengkapi antara satu dengan yang lainnya. Lembaga legislatif seringkali diidentikan dengan Dewan Perwakilan rakyat, sedangkan lembaga yudikatif seringkali dilambangkan dengan lembaga peradilan atau pelaksana.

Dewan Perwakilan Rakyat (DPR) disebut-sebut sebagai pemegang mandat atau wakil dari kedaulatan rakyat yang memiliki posisi tertinggi 
dalam pelaksanaan kehidupan berbangsa dan bernegara di Indonesia ini. Kedaulatan (sovereignty) merupakan konsep dalam filsafat politik dan hukum ketatanegaraan, didalamnya terkandung konsepsi yang berkaitan dengan ide kekuasaan tertinggi yang dikaitkan dengan negara. Pengertian kedaulatan itu sendiri sebenarnya berasal dari bahasa Arab yang dalam arti klasiknya berarti pergantian, peralihan atau peredaran (kekuasaan). ${ }^{1}$ Sedangkan dalam dalam literatur politik, hukum dan teori kenegaraan pada jaman sekarang diartikan sebagai penguasa dan kekuasaan yang tertinggi.

Tokoh yang dianggap sebagai pelopor pertama yang membahas ide kedaulatan ini sebagai konsep kekuasaan tertinggi adalah Jean Bodin (1530-1596). Dalam buku karya monumentalnya yang berjudul Six Livres de la Republique dikatakan bahwa kedaulatan (dalam pandangan klasik) itu tidak dapat dipisahkan dari negara, tanpa kedaulatan apa yang dinamakan negara tidak ada, karena tidak berjiwa, dan di katakan Bodin: ${ }^{2}$

Pertama, bahwa kedaulatan itu bersifat mutlak, abadi dan karena itu juga harus bersifat utuh, tunggal dan tidak terbagi-bagi atau terpecah-pecah serta bersifat tertinggi dalam arti tidak terderivasikan dari kekuasaan yang lebih tinggi. Kedua, kekuasaan berdaulat dalam negara itu berkaitan dengan fungsi legislatif, yaitu negara itu berdaulat dalam membuat hukum atau undang-undang dan atau menghapuskan hukum, dan Ketiga, hukum itu sendiri merupakan perintah dari yang berdaulat tersebut yang pada jamannya memang berada di tangan Raja.

Adapun konsep kedaulatan menurut Jean Jaques Rosseau ${ }^{3}$ bersifat kerakyatan dan didasarkan pada kemauan umum (volunte general) rakyat yang menjelma melalui perundang-undangan. Oleh sebab itu, menurutnya, konsep kedaulatan mempunyai sifat-sifat, yaitu: 1) Kesatuan (unite), bersifat monistis; 2) Bulat dan tak terbagi (indivisibilite); 3) Tidak dapat dialihkan (inalienabilite); dan 4) Tidak dapat berubah (imprescriptibilite).

Konsep kedaulatan bersifat kesatuan (unite) dalam arti bahwa semangat rakyat dan kemauan umum rakyat itu adalah satu kesatuan dimana mereka sebagai kesatuan berhak memerintah dan berhak

1 Al-Mawrid, A Modern English-Arabic Dictionary (t.t.: Dar El Ilmi lil Malayen. 1979), hlm. 882.

2 Jimly Assiddiqie, Konstitusi \& Konstitusionalisme Indonesia (Jakarta: Sekretariat Jendral dan Kepaniteraan Mahkamah Konstitusi RI. 2006, hlm. 122-123.

3 Ibid., hlm. 126-127. 
menolak perintah. Karena rakyat adalah satu maka Negara adalah satu juga. Karena itu pula, konsep kedaulatan itu bersifat bulat dan tak dapat dipecah-pecah (indivisible).

Negara Indonesia menganut sistem pemerintahan republik, artinya disini terjadi dominasi kekuasaan yang dimiliki oleh rakyat. Dalam kekuasaan rakyat ini, maka segala bentuk kebijakan yang menyangkut hajat orang banyak maka harus dikembalikan kepada rakyat. Artinya, kebijakan tersebut harus bertujuan demi kesejahteraan rakyat itu sendiri. Indonesia menganut kedaulatan tersebut.

Begitu penting dan strategisnya peranan lembaga Dewan Perwakilan Rakyat yang akan menentukan nasib berbangsa dan bernegara, maka sudah sepatutnya harus mendapat perhatian jika terhinggap suatu permasalahan. Namun, keberadaan anggota DPR tidak bisa terlepas dari dominasi partai politik. Karena anggota DPR merupakan rekomendasi dari partai politik. Hal inilah yang menjadi titik permasalahan dan kelemahan tersendiri bagi lembaga ini. Yang menjadi fokus dalam penelitian ini adalah mengenai kedudukan seorang presiden terhadap kasus recall dalam kajian konsep Ahlul halli wal 'aqdi.

\section{B. DPR, Partai Politik dan Hak Recall}

Kendala dari keberadaan anggota DPR adalah dominasi partai poltik. Hal tersebut wajar saja, mengingat asal anggota DPR itu sendiri yang berasal dari partai politik. Namun demikian, bukan berarti kedaulatan rakyat harus tunduk terhadap aturan dan kebijakan partai politik hanya karena alasan tersebut. karena seringkali arogansi partai politik melalui hak recallnya menuai kontroversi.

Pasal 16 Ayat (3) Undang-Undang Dasar Republik Indonesia tahun 1945, menyatakan bahwa:

(3) Dalam hal anggota Partai Politik yang diberhentikan adalah anggota lembaga perwakilan rakyat, pemberhentian dari keanggotaan Partai Politik diikuti dengan pemberhentian dari keanggotaan di lembaga perwakilan rakyat sesuai dengan peraturan perundang-undangan.

Pasal 12 Huruf (h) Undang-Undang Nomor 2 Tahun 2008 juncto Undang-Undang Nomor 2 Tahun 2011 tentang Partai Politik, menyatakan bahwa partai politik berhak mengusulkan pemberhentian anggotanya di Dewan Perwakilan Rakyat dan Dewan Perwakilan Rakyat Daerah sesuai dengan peraturan perundang-undangan; 
Undang-Undang Nomor 17 Tahun 2014 Perubahan atas UndangUndang Nomor 27 Tahun 2009 Tentang Majelis Permusyawaratan Rakyat, Dewan Perwakilan Rakyat, Dewan Perwakilan Daerah, dan Dewan Perwakilan Rakyat Daerah, ditentukan bahwa seorang anggota Dewan Perwakilan Rakyat (DPR) dapat diberhentikan dari keanggotaannya di Dewan Perwakilan Rakyat (DPR) lewat Pemberhentian Antar Waktu (PAW), ${ }^{4}$ apabila :

1. Tidak dapat melaksanakan tugas secara berkelanjutan atau berhalangan tetap sebagai anggota DPR selama 3 (tiga) bulan berturutturut tanpa keterangan apapun;

2. Melanggar sumpah/janji jabatan dan kode etik DPR;

3. Dinyatakan bersalah berdasarkan putusan pengadilan yang telah memperoleh kekuatan hukum tetap karena melakukan tindak pidana yang diancam dengan pidana penjara 5 (lima) tahun atau lebih;

4. Diusulkan oleh partai politiknya sesuai dengan ketentuan peraturan perundang- undangan;

5. Tidak lagi memenuhi syarat sebagai calon anggota DPR sesuai dengan ketentuan peraturan perundangundangan mengenai pemilihan umum anggota DPR, DPD, dan DPRD;

6. Melanggar ketentuan larangan sebagaimana diatur dalam UndangUndang ini;

7. Diberhentikan sebagai anggota partai politik sesuai dengan ketentuan peraturan perundang-undangan; atau

8. Menjadi anggota partai politik lain.

Berdasarkan uraian peraturan tersebut terlihat bahwa recall merupakan hak perogratif partai politik. Pertanyaannya, apakah mungkin seorang anggota legislatif yang merupakan wakil (representtation) rakyat dan dipilih melalui mekanisme demokratis dapat diberhentikan semaunya oleh partai politiknya? Eksistensi seorang anggota Dewan Perwakilan Rakyat yang merupakan perwujudan kedaulatan rakyat seketika itu juga harus berakhir melalui mekanisme recall partai politik. Padahal hakikatnya tupoksi sebuah lembaga partai politik hanya sebatas tempat perkaderan dan pendidikan politik serta tak lebih dari itu. Artinya, anggota partai politik yang berada di DPR merupakan representasi rakyat, bukan kepanjangan tangan partai politik. 
Secara logika, sekalipun jumlah keseluruhan anggota partai politik dalam lingkup kota/kabupaten, provinsi maupun pusat memilih salah satu kadernya untuk menjadi anggota DPR tidak akan cukup. Belum harus memperhatikan daerah pemilihan, kader yang lain dan lain sebagainya. Akibat penginterpretsian yang salah dari recall, telah memunculkan sebuah pertanyaan tentang kedudukan presiden dalam sengketa Pemberhentian Antar Waktu (PAW) atau recall. Polemiknya adalah tentang penyelesaian sengketa recall melalui peradilan Tata Usaha Negara (TUN). Standar dan ukuran keputusan sehingga menjadi KTUN sebagaimana yang dikemukakan oleh Marbun dan Mahfud, ukurannya adalah: 5

1. Perbuatan pemerintah itu adalah perbuatan hukum publik yang bersegi satu atau sepihak dari pemerintah (bukan merupakan hasil persetujuan kedua belah pihak);

2. Sifat hukum publik tersebut diperoleh karena adanya wewenang atau kekuasaan istimewa; dan

3. Tindakan pemerintahan itu dimaksudkan terjadi perubahan dalam lapangan hubungan hukum.

Perkara yang menjadi kewenangan PTUN haruslah sesuai dengan pengertian dan syarat-syarat perkara Keputusan Tata Usaha Negara, adapun pengertian yang menjadi standar ukuran pangkal sengketa yaitu sengketa administrasi yang diakibatkan oleh ketetapan sebagai hasil perbuatan pejabat administrasi negara. Secara spesifik pengertian Keputusan Tata Usaha Negara (KTUN) ditegaskan dalam Pasal 1 angka 3 Undang-undang Nomor 5 tahun 1986 tentang PTUN. Keputusan Tata Usaha Negara (KTUN) adalah:

Suatu penetapan tertulis yang dikeluarkan oleh badan atau pejabat Tata Usaha Negara yang berisi tindakan hukum Tata Usaha Negara berdasarkan peraturan perundang-undangan yang berlaku, yang bersifat konkret, individual, dan final, yang menimbulkan akibat hukum bagi seorang atau badan hukum perdata.

Berdasarkan pengertian tersebut, maka ada beberapa syarat yang harus dipenuhi oleh suatu perkara yang dalam hal ini mengenai sengketa Pemberhentian Antar Waktu (PAW) atau recall, untuk bisa dikategorikan sebagai Keputusan Tata Usaha Negara (KTUN). Identifikasinya adalah sebagai berikut:

5 SF. Marbun, Moh Mahfud MD, Pokok-Pokok Hukum Administrasi Negara (Yogyakarta: Liberty. 2006), hlm. 75-77. 
1. Keputusan itu mesti tertulis;

2. Keputusan dikeluarkan oleh badan atau pejabat TUN;

3. Keputusan harus mengandung unsur tindakan Tata Usaha Negara;

4. Keputusan harus berdasarkan perundang-undangan yang berlaku;

5. Keputusan harus bersifat konkret, individual dan final; dan

6. Keputusan tersebut menimbulkan akibat hokum.

Berdasarkan uraian tersebut, maka kedudukan perkara PAW/recall anggota DPR dikatakan sebagai tindakan tata usaha negara yang dilakukan oleh Presiden atau bukan, karena di dalam Pasal 240 ayat 4 Undang-undang Nomor 17 Tahun 2014, disebutkan bahwa Presiden hanya meresmikan usul PAW yang diusulkan oleh pimpinan DPR. Sehingga terjadi multitafsir dan menimbulkan spekulasi di kalangan Hakim PTUN tentang ketetapan peresmian PAW anggota DPR tersebut. Setiap hakim PTUN memiliki perbedaan tafsiran pada Pasal 240 ayat 4 Undang-undang Nomor 17 Tahun 2014. Unsur dari "meresmikan" yang dihubungkan dengan unsur KTUN yaitu "keputusan berisi tindakan Hukum Tata Usaha Negara".

Apakah sama arti dari "meresmikan" dengan "tindakan", pada kata meresmikan sebagian hakim menilai bahwa ini bukan tindakan tata usaha Negara, karena Presiden hanya meresmikan saja. Maka perkara recall tidak termasuk kedalam KTUN, karena Presiden dalam meresmikan tidak mempunyai kehendak/willforming. Presiden dalam mengambil keputusan hanya meresmikan PAW anggota DPR. Presiden tidak mempunyai suatu kehendak untuk menolak ataupun menentukan lain terhadap mekanisme PAW anggota DPR. Semua proses sudah terjadi dan diusulkan oleh partai politik yang bersangkutan dan telah diverifikasi oleh KPU. Presiden tinggal meresmikan saja. Padahal terpenuhinya suatu objek gugatan sebagai pangkal sengketa TUN, mestinya suatu surat keputusan Tata Usaha Negara tergugat pejabat TUN ada kehendak di dalamnya. Presiden harus menentukan apa yang harus dilakukannya.

Multi tafsir dalam penyelesaian kasus recall ini terkesan sangat mengistimewakan partai politik yang memiliki kekuasaan penuh, sementara kedudukan presiden hanya sebatas simbol dan bertugas mengamini saja setiap apa yang dikehendakai oleh partai politik. Seharusnya kedudukan seorang presiden atau pemimpin diatas segala lembaga yang ada, apa lagi partai politik dan bukan sebaliknya. 


\section{Kajian konsep Ahlul Halli Wal 'Aqdi terhadap kasus Recall}

Istilah Ahlul Halli Wal 'Aqdi barasal dari tiga suku kata, yaitu ahlun, hallun dan aqdun. Dalam kamus bahasa arab kata "Ahl" mempunyai arti ahli atau keluarga. ${ }^{6}$ sedangkan kata "Hallu" berarti membuka atau menguraikan,7 sedangkan "Aqd" berarti kesepakatan/mengikat. ${ }^{8}$ Dari ketiga suku kata tersebut dapat dirangkai menjadi sebuah kata (istilah) yang mempunyai arti "orang-orang yang mempunyai wewenang melonggarkan dan mengikat."9 Istilah ini dirumuskan oleh ulama fikih untuk sebutan bagi orang-orang yang bertindak sebagai wakil umat untuk menyuarakan hati nurani mereka. Paradigma pemikiran ulama fikih merumuskan istilah Ahlul Halli Wal Aqdi didasarkan pada sistem pemilihan empat khalifah pertama yang dilaksanakan oleh para tokoh sahabat yang mewakili dua golongan, Ansar dan Muhajirin. Mereka ini oleh ulama fikih diklaim sebagai Ahlul Halli Wal Aqdi yang bertindak sebagai wakil umat.

Dalam terminologi politik ahlul halli wal 'aqdi bisa dikategorikan dewan perwakilan (lembaga legislatif) sebagai representasi dari seluruh masyarakat (rakyat) yang akan memilih kepala negara serta menampung dan melaksanakan aspirasi rakyat. Dalam hal ini, Mawardi mendefinisikan ahlul halli wal aqdi sebagai kelompok orang yang dipilih oleh kepala negara untuk memilih kepala negara yang akan menggantikan kepala negara yang lama. Namun Mawardi tidak menjelaskan tentang unsur-unsur dari ahlul halli wal aqdi.

Istilah Ahlul Halli Wal Aqdi mulai timbul dalam kitab-kitab para ahli tafsir dan ahli fikih setelah masa Rasulullah saw. Mereka berada di antara orang-orang yang dinamakan dengan Al-Shahabah. ${ }^{10}$

Menurut Al-Nawawi dalam Al-Minhaj, Ahlul Halli Wal Aqdi adalah para ulama, para kepala, para pemuka masyarakat yang berusaha mewujudkan kemaslahatan rakyat. Muhammad Abduh menyamakan Ahlul Halli Wal Aqdi dengan ulil amri yang disebut dalam Al-Quran surat an-Nisa' ayat 59 yang menyatakan:

6 Mahmud Yunus, Qamus Arab-Indonesia (Jakarta: Yayasan Penyelenggara Penterjemah dan Penafsir al-Quran. 1973), cet. ke-1, hlm. 53.

7 Ibid., hlm. 106.

8 Ibid., hlm. 257.

9 J. Suyuthi Pulungan, Fiqh Siyasah: Ajaran, Sejarah dan Pemikiran (Jakarta: Raja Grafindo Persada. 2002), cet. ke-5, hlm. 66.

10 Farid Abdul Kholiq, Fikih Politik Islam (Jakarta: Amzah. 2005), hlm. 78. 


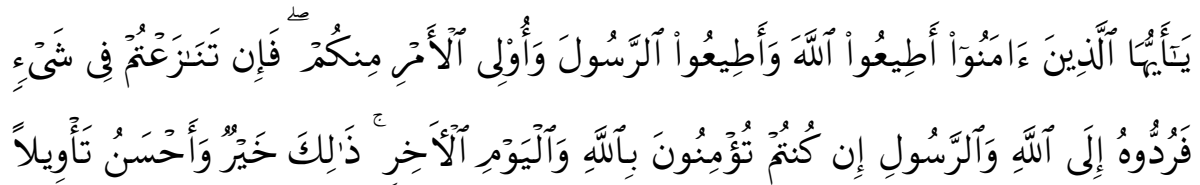

Hai orang-orang yang beriman, taatilah Allah dan taatilah Rasul (Nya), dan ulil amri di antara kamu. Kemudian jika kamu berlainan pendapat tentang sesuatu, maka kembalikanlah ia kepada Allah (Al Quran) dan Rasul (sunnahnya), jika kamu benarbenar beriman kepada Allah dan hari kemudian. Yang demikian itu lebih utama (bagimu) dan lebih baik akibatnya.

Ia menafisirkan ulil amri dan Ahlul Halli Wal Aqdi sebagai kumpulan orang dari berbagai profesi dan keahlian yang ada dalam masyarakat. Abduh menyatakan, yang dimaksud dengan ulil amri adalah kalangan orang-orang muslim. Mereka itu adalah para amir, para hakim, para ulama, para pimpinan militer dan semua pengusaha dan pemimpin yang dijadikan rujukan oleh umat dalam masalah kebutuhan dan kemaslahatan publik.

Lebih lanjut ia menjelaskan, apabila mereka sepakat atas suatu urusan atau hukum maka umat wajib mentaatinya dengan syarat mereka itu adalah orang-orang muslim dan tidak melanggar perintah Allah dan Sunnah Rasul yang mutawatir.11 Al-Razi juga menyamakan pengertian antara Ahlul Halli Wal Aqdid dengan ulil amri, yaitu para pemimpin dan penguasa. Demikian juga Al-Maraghi yang sependapat dengan apa yang diungkapkan Rasyid Ridha dan Muhammad Abduh. ${ }^{12}$

Dengan demikian, Ahlul Halli Wal Aqdi terdiri dari berbagai kelompok sosial yang memiliki profesi dan keahlian yang berbeda, baik dari birokrat pemerintahan maupun tidak yang lazim disebut pemimpin formal dan pemimpin informal. ${ }^{13}$ Tidak semua pemimpin dan pemuka profesi dan keahlian yang disebut otomatis adalah anggota dari Ahlul Halli Wal Aqdi, sebab anggota lembaga ini harus memenuhi kualifikasi. Al-Mawardi dan Rasyid Ridha merumuskan beberapa syarat, yaitu berlaku adil dalam setiap sikap dan tindakan, berilmu pengetahuan, dan memiliki wawasan dan kearifan. Dengan kualifikasi ini diharapkan

\footnotetext{
11 Ibid., hlm. 68.

12 Ibid., hlm. 69.

13 Ibid.
} 
golongan Ahlul Halli Wal Aqdi dapat menentukan siapa diantara ahl alimamat yang pantas menjadi kepala negara menurut syarat-syarat yang ditentukan, dan mampu memegang jabatan itu untuk mengelola urusan negara dan rakyat. ${ }^{14}$

Dalam bukunya Farid Abdul Kholiq memastikan bahwa kelompok Ahlul Halli Wal Aqdi yang sering dipakai dalam istilah turats fikih sejak awal Islam adalah mereka "Dewan Perwakilan Rakyat" atau yang biasa disebut Ahlul Ikhtiyar, yang para khalifah selalu merujuk kepada mereka dalam perkara-perkara rakyat juga berkomitmen dengan pendapat mereka, dan mereka mempunyai hak untuk memilih atau menobatkan khalifah juga memberhentikannya. Ahlul Halli Wal Aqdi terdiri dari para ulama, para pemimpin suku dan pemuka masyarakat yang menguatkan mereka sebagai lembaga legislatif. ${ }^{15}$

Dari penjelasan di atas, para fukaha berpendapat bahwa syaratsyarat untuk menjadi Ahlul Halli Wal Aqdi bersifat fleksibel (tidak terbatas), antara lain:

1. Adil dari segi akhlak yang paling utama;

2. Mempunyai ilmu pengetahuan; dan

3. Ahli Ikhtiyar harus terdiri dari para pakar dan ahli manajemen. ${ }^{16}$

Pentingnya arti pemimpin, maka Islam menaruh perhatian yang sangat besar terhadapnya. Definisi tentang pemimpin memiliki banyak variasi dan banyak yang mencoba untuk mendefinisikan tentang konsep pemimpin ini. Pemimpin adalah orang yang memiliki segala kelebihan dari orang-orang lain.

Pemimpin dalam pandangan orang kuno adalah mereka yang dianggap paling pandai tentang berbagai hal yang ada hubungannya kepada kelompok dan pemimpin harus pandai melakukannya (pandai memburu, cakap dan pemberani berperang).17 Jika dikaitkan dengan zaman sekarang ini pemimpin tidak harus bisa memenuhi tugas seperti pada zaman dulu, akan tetapi pemimpin harus memikliki kecakapan, pemimpin sekarang ini hanya memilih seorang pembantu yang mempunyai keahlian yang berkaitan dengan apa yang belum dia miliki artinya sesuai dengan keahlian. ${ }^{18}$
14 Ibid., hlm. 69-70.
15 Ibid., hlm. 79.
16 Ibid., hlm. 109-113.
17 Ngalim Purwanto dkk, Administrasi Pendidikan (Jakarta: Mutiara. 1984), hlm. 38.

18 Ibid. 
Dalam Al-Qur'an kategori pemimpin dapat di jabarkan ke dalam istilah, yakni khalīfah, Imāmah dan Imām. Khalīfah ${ }^{19}$ berasal dari kata khalafa yang memiliki makna pengganti/ yang menggantikan, Sebagaimana terdapat dalam Al-Qur'an pada Qs. Al-Baqarah ayat 30:

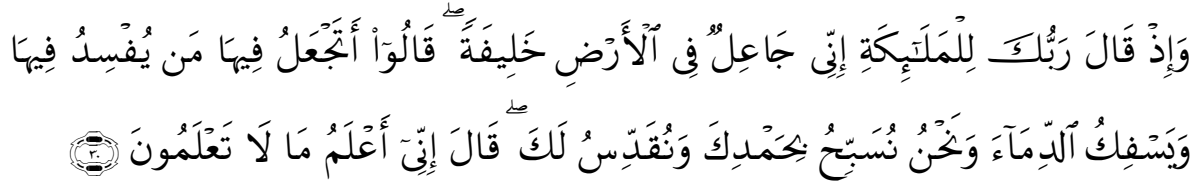

Ingatlah ketika Tuhanmu berfirman kepada Para Malaikat: "Sesungguhnya aku hendak menjadikan seorang khalīfah di muka bumi." mereka berkata: "Mengapa Engkau hendak menjadikan (khalīfah) di bumi itu orang yang akan membuat kerusakan padanya dan menumpahkan darah, Padahal Kami Senantiasa bertasbih dengan memuji Engkau dan mensucikan Engkau?" Tuhan berfirman: "Sesungguhnya aku mengetahui apa yang tidak kamu ketahui." 20

Maksud dari surah Al-Baqarah ayat 30 di atas dalam tafsir alMisbah menyatakan bahwa ayat ini merupakan penyampaian Allah kepada malaikat tentang rencana-Nya menciptakan manusia di muka bumi ini. Penyampaian kepada mereka menjadi sangat penting, karena malaikat akan dibebani sekian tugas menyangkut manusia. Ada yang akan bertugas mencatat ama-amal manusia, ada yang bertugas memelihara dan membimbingnya. ${ }^{21}$

Penyampaian ini bisa jadi merupakan bagian dari proses penciptaan alam raya dan kesiapannya untuk dihuni manusia pertama (Adam) dengan nyaman. Maksud Allah ini kemudian didengar oleh malaikat dan malaikat lalu bertanya tentang makna penciptaan tersebut. Mereka menduga bahwa khalifah (manusia) ini akan merusak dan menumpahkan darah. ${ }^{22}$ Dugaan ini berdasarkan pada pengalaman

${ }^{19}$ Di jelaskan di dalam tafsir A-Misbah kata khalifah pada mulanya memiliki arti "yang menggantikan atau yang datang sesudah siapa yang datang sebelumnya". Ada juga yang memberikan makna yang "menggantikan Allah", bukan Dia tidak mampu untuk menjadikan manusia menjadi tuhan, akan tetapi ini merupakan ujian bagi manusia, dan memberi penghormatan kepada manusia. Lihat M. Quraish Shihab, Tafsir Al-Misbah (Pesan dan Kesan Keserasian al-Quran) Jakarta: Lentera Hati. 2004), cet. Ke-2, vol. I, hlm. 140.

20 Tim Penyusun Departemen Agama, al-Qur'an dan Terjemahnya (Surakarta: Media Insani Publishing. 2007), hlm. 6.

${ }^{21}$ M. Quraish Shihab, Tafsir Al-Misbah. hlm. 140.

22 Dalam proses penciptaan manusia sebagai khalifah di Bumi (Adam), terjadi penolakan dari mahluk-mahluk yang lain, yakni Malaikat. Mereka merasa dia lebih hebat 
mereka sebelumnya. Pertanyaan mereka juga bisa lahir penamaan Allah terhadap makhluk yang akan diciptakan itu dengan khalifah. ${ }^{23}$

Menurut Ibnu Katsir, Imam Al-Qurthubi dan ulama' yang lain telah menjadikan ayat ini sebagai dalil wajibnya menegakkan khilafah untuk menyelesaikan dan memutuskan pertentangan antara manusia, menolong orang yang teraniaya, menegakkan hukum Islam, mencegah merajalelanya kejahatan dan masalah-masalah lain yang tidak dapat terselesaikan kecuali dengan adanya imam (pimpinan). ${ }^{24}$

Sebagaimana dalam hadits yang diriwayatkan oleh Imam Bukhari dan Imam Muslim:

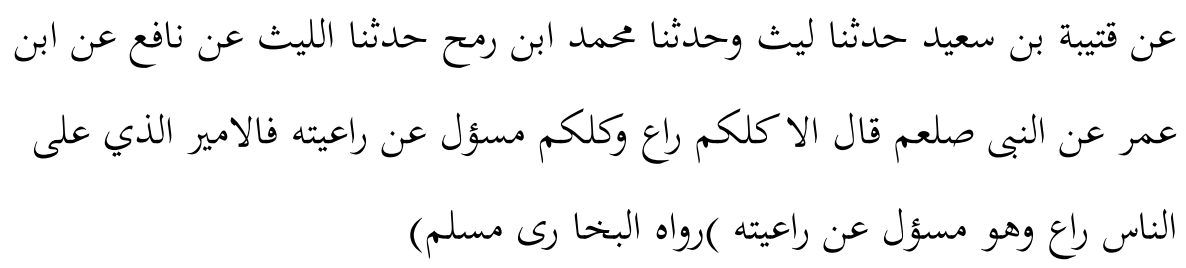

Dari Qutiabah bin Said dari Laits, Saya juga di ceritai oleh Muhammad bin Ramah dari laits dari Nafi dari Ibn Umar bahwa Rasullulah SAW berkata: "Ingatlah setiap kalian adalah pemimpin, dan setiap kalian akan ditanya tentang kepemimpinannya, penguasa adalah pemimpin dan akan ditanya tentang kepemimpinannya. (HR. Bukhari dan Muslim). ${ }^{25}$

Kedudukan seorang pemimpin menurut konsep Ahlul halli wal 'aqdi, dapat rumuskan sebagai berikut: Pertama, pemimpin adalah sebagai pemangku kekuasaan tertinggi, pemimpin memiliki kewe-

banding dengan manusia, pada dasarnya, mereka beranggapan dengan adanya manusia, maka akan terjadi malapetaka di muka bumi ini seperti pengalaman yang dulu. Malaikat beralasan bahwa mereka diciptakan dari Nur. Hal serupa ditandaskan oleh mahluk yang bernama Iblis, dia merasa lebih hebat dari manusia, dengan argumen dia di ciptakan dari api, sedangkan manusia diciptakan dari tanah. Iblis sangat kecewa dengan kehadiran manusia, karena mereka tidak dianggap sebagai wakil-Nya untuk menjaga Bumi. Untuk itu, Iblis bersumpah kapada Allah, akan mengganggu manusia sepanjang zaman. Lihat Achmad Chodjim, Membangun Surga (Jakarta: PT. Serambi Ilmu Semesta, cet, ke-1, 2004, hlm. 174.

23 M. Quraish Shihab, Tafsir Al-Misbah. hlm. 140.

24 M. Hasib Ar-Rifa'i, Kemudahan dari Allah Ringkasan Tafsir Ibnu Katsir (Jakarta: Gema Insani. 1999), hlm. 104.

25 Muslim, Shahih Muslim (Libanon: Dar Al Kutub Bairud. t.th.), juz II, hlm. 125. Lihat juga Ahmad ibnu Ali Ibnu Hajar Al Asqalani, Fathul Barri (Libanon: Dar Al Kutub. t.th.), juz II, hlm. 380 . 
nangan untuk mengambil segala bentuk kebjakan, baik itu menyangkut produk hukum, militer, pembangunan atau yang lainnya.

Kedua, keberadaan pemimpin tersebut merupakan pengangkatan yang dilakukan oleh Ahlul halli wal 'aqdi yang berdasarkan atas mandat dari rakyat, maka pemimpin harus bertanggungjawab terhadap Ahlul Hal Wal Aqdi ketika masa jabatannya berakhir.

Ketiga, kedudukan Ahlul halli wal 'aqdi hanya sebatas pemberi masukan, saran dan konsultasi kepada pemimpin dalam rangka sebagai bahan pertimbangan untuk mengambil kebiijakan yang berkaitan dengan berbagai bidang atau aspek keahlian yang dimiliki oleh Ahlul Halli Wal Aqdi.

Keempat, pengangkatan pemimpin yang dilakukan oleh Ahlul Halli Wal Aqdi sangat berpotensi meminimalisir kepentingan-kepentingan segelintir orang yang menyampingkan kepentingan umat, karena komposisi Ahlul Halli Wal Aqdi itu sendiri merupakan orang-orang professional yang memiliki kapabilitas di bidangnya masing-masing dan memiliki mandat rakyat, tidak seperti partai politik yang berlandaskan kepentingan golongan partai.

Kelima, pemimpin yang melakukan penyelewengan kekeuasaan (abuse of power), maka dalam penanganannya dilakukan oleh Ahlul Halli Wal Aqdi, karena seperti yang dikemukakan oleh Al-Maududi tentang kewenangan Ahlul Halli Wal Aqdi yang melingkupi ketiga bidang, yaitu eksekutif, legislatif dan yudikatif. 26

Seorang pemimpin memiliki mandat yang sangat besar dan memegang puncak pimpinan. Seorang pemimpin harus pandai mengatur dan memilah serta menempatkan keprofesionalan, kompetensi, keahlian dan spesialisasi sumber daya manusia yang akan menjadi pembantu dalam mewujudkan cita-cita kepemimpinannya, bukan sebaliknya yang hanya serba "tahu beres" atau "tidak mau ribet". Karena hakikatnya segala bentuk keputusan tertinggi berada pada kehendak seorang pemimpin.

\section{Penutup}

Pelaksanaan recall sebagai hak yang dimiliki oleh partai politik cenderung bersifat tertutup dan memiliki kesan politis, dalam pengaturannyapun banyak terdapat multi tafsir pada Undang-Undang

26 Muhammad Iqbal dan Amien Husein Nasution, Pemikiran Politik Islam (Jakarta: Prenada Media Group. 2010), hlm. 184-185. 
yang mengatur tentang hak recall tersebut. Akibatnya, banyak alasanalasan pemberlakuan recall semaunya partai politik. Perihal sengketa penyelesaian kasus recall yang berujung kepada pertanyaan tentang kedudukan seorang presiden sebagaimana yang telah diatur dalam Pasal 240 ayat 4 Undang-undang Nomor 17 Tahun 2014, adalah buah akibat dari ketidakjelasan sistem pemerintahan. Dalam konsep ahlul halli wal 'aqdi, seorang pemimpin haruslah menjadi pemegang puncak kebijakan dan sebagai jalan terakhir penyelesaian segala bentuk permasalahan. Karena keserakahan kekuasaan yang dilakukan oleh segelintir orang yang tergabung dalam partai politik tersebut menimbulkan penyelewengan kekuasaan (abuse of power), hingga pada akhirnya sampai pada perlakuan politisasi di wilayah legislasi. Padahal, anggota DPR merupakan bagian dari kelengkapan pimpinan negara haruslah memperhatikan khittah keberadaannya sebagai wakil rakyat yang seyogyanya memiliki spesialisasi dan kapabilitas di berbagai bidangnya masing-masing dalam melaksanakan tugas. Kesejahteraan umat dan rakyat harus menjadi perhatian utama anggota DPR ketimbang memperhatikan kepentingan dan keberadaan partai politiknya. Partai pollitik tidak lain hanya sebatas tempat pendidikan, kaderisasi dan jembatan politik, kontrak politik yang sesungguhnya adalah antara anggota DPR dengan rakyat yang diwakilinya.

\section{DAFTAR PUSTAKA}

Al-Maududi, Abul A'la. 1990. The Islamic Law and Constitutional. Terj. Asep Hikmat. "Hukum dan Konstitusi: Sistem Politik Islam". Bandung: Mizan.

Al-Mawardi, Imam. 1994. Al-Hawi al-Kabir. Beirut: Dar Al-Kitab AlIlmiyah.

Al-Mawardi, Imam. 2000. Al-Ahkam al-Sulthaniyah wa al-Wilayatu alDiniyah. Terj. Abdul Hayyie al-Kattani dan Kamaluddin Nurdin. "Hukum Tata Negara dan Kepemimpinan dalam Takaran Islam". Jakarta: Gema Insani Press.

Al-Mawrid. 1979. A Modern English-Arabic Dictionary. t.t.: Dar El Ilmi lil Malayen. 
An-Nabhani, Taqiyyuddin. 2002. Daulah Islam Edisi Mu'tamadah. Terj. Umar Faruq. Jakarta: HTI Press.

Ar-Rifa'i, M. Hasib. 1999. Kemudahan dari Allah Ringkasan Tafsir Ibnu Katsir. Jakarta: Gema Insani.

Assiddiqie, Jimly. 2006. Konstitusi \& Konstitusionalisme Indonesia. Jakarta: Sekretariat Jendral dan Kepaniteraan Mahkamah Konstitusi RI.

Hasan, Hasan Ibrahim. 1964. Tarikh al-Islami: al-Siyasy wa al-Diny wa alTsaqafi wa al- Ijtima'i. Beirut: Dar al-Fikr.

Iqbal, Muhammad dan Amien Husein Nasution. 2010. Pemikiran Politik Islam. Jakarta: Prenada Media Group.

Karim, Khalil Abdul. 2002. Quraisy min al-Qabilah ila al-Din alMarkaziyyah. Terj. M. Faisol Fatawi. "Hegemoni Quraisy: Agama, Budaya dan Kekuasaan". Yogyakarta: LkiS.

Khan, Qamaruddin. 2000. Al-Mawardi's Theory of the State. Terj. Imron Rosyidi. "Kekuasaan, Pengkhianatan dan Otoritas Agama: Telaah Kritis Teori Al-Mawardi Tentang Negara". Yogyakarta: Tiara Wacana Yogya.

Kholiq, Farid Abdul. 2005. Fikih Politik Islam. Jakarta: Amzah.

Pulungan, J. Suyuthi. 2002. Fiqh Siyasah: Ajaran, Sejarah dan Pemikiran. Jakarta: PT. Raja Grafindo Persada.

Purwanto, Ngalim dkk. 1984. Administrasi Pendidikan. Jakarta: Mutiara.

Rais, Dhiauddin. 2001. An-Nazhariyatu As-Siyasatu Al-Islamiyah. Terj. Abdul Hayyie al- Kattani "Teori Politik Islam". Jakarta: Gema Insani Press.

Rivai, Veithzal. 2003. Kepemimpinan dan Prilaku Organisasi. Jakarta: PT. Raja Grafindo Persada.

Sjadzali, Munawir. 1990. Islam dan Tata Negara: Ajaran, Sejarah dan Pemikiran. Jakarata: UI Press.

Yatim, Badri. 2000. Sejarah Peradaban Islam. Jakarata: PT. Raja Grafindo Persada. 
50 |'AOltyA Vol.10, No.1, Juni 2016

Yunus, Mahmud. 1973. Qamus Arab-Indonesia. Jakarta: Yayasan Penyelenggara Penterjemah dan Penatfsir al-Qur'an. 